\title{
Molecular identification of Ammonia and Elphidium species (Foraminifera, Rotaliida) from the Kiel Fjord (SW Baltic Sea) with rDNA sequences
}

\author{
Magali Schweizer $\cdot$ Irina Polovodova \\ Anna Nikulina · Joachim Schönfeld
}

Received: 18 September 2009/Revised: 15 February 2010/Accepted: 2 March 2010/Published online: 28 March 2010

(C) Springer-Verlag and AWI 2010

\begin{abstract}
Ammonia and Elphidium collected in the Kiel Fjord for the present study were first identified on morphological bases as Ammonia beccarii (Linné, 1758) and Elphidium excavatum (Terquem, 1876). Phylogenetic analyses based on partial SSU rDNA and LSU rDNA sequences show that Ammonia specimens sampled in the Kiel Fjord belong to the phylotype T6, which has a disjunct distribution (Wadden and Baltic Seas/China and Japan) and has been identified as Ammonia aomoriensis (Asano, 1951). Partial SSU rDNA sequence analyses indicate that Elphidium specimens from the Kiel Fjord belong to the clade E. excavatum, confirming the morphological identification. This clade can be further divided in three subclades. Kiel Fjord Elphidium belong to two of these subclades and were identified morphologically as the
\end{abstract}

Communicated by H.-D. Franke.

M. Schweizer

Geological Institute, ETHZ, Sonneggstrasse 5,

8092 Zurich, Switzerland

Present Address:

M. Schweizer $(\square)$

Grant Institute of Earth Science, School of GeoSciences,

University of Edinburgh, West Mains Road,

Edinburgh EH9 3JW, UK

e-mail: magali.schweizer@ed.ac.uk

I. Polovodova $\cdot$ A. Nikulina $\cdot$ J. Schönfeld

Leibniz Institute for Marine Sciences IFM-GEOMAR,

Wischhofstrasse 1-3, 24148 Kiel, Germany

Present Address:

I. Polovodova

Department of Earth Sciences, University of Gothenburg,

PO Box 460, 40530 Göteborg, Sweden subspecies E. excavatum excavatum (Terquem, 1876) and E. e. clavatum Cushman, 1930.

Keywords Benthic foraminifers - Ammonia Elphidium . Molecular identification $\cdot$ rDNA sequence $\cdot$ Kiel Fjord

\section{Introduction}

Ammonia and Elphidium are the two most abundant benthic foraminiferal genera worldwide (Murray 1991). Elphidium species occur from tropical to polar regions and from the intertidal zones to the continental slope (Murray 2006). Ammonia species are found from the subtidal to the outer continental shelves. They avoid the high latitudes, having therefore a more restricted distribution (Walton and Sloan 1990; Murray 2006). Ammonia and Elphidium species are important constituents of the benthic foraminiferal faunas from the European marginal seas. In the shallow Mediterranean, English Channel, North Sea and western Baltic Sea, these genera constitute a high proportion of the living foraminiferal assemblages (Murray 1991). Their tests are readily preserved in the fossil record and serve as proxies for paleoenvironmental analyses (e.g. Kubisch and Schönfeld 1985; Poignant et al. 2000; Xiang et al. 2008).

Taxonomy of Ammonia and Elphidium

Despite the widespread occurrence and ecological relevance of Ammonia and Elphidium, the taxonomy of these genera has been the subject of long-standing controversies. More than 40 species, subspecies or varieties of recent Ammonia have been described (Ellis and Messina 1940 and supplements). A culture study of Ammonia (Schnitker 1974) revealed that the offspring of a single specimen 
showed seven different morphotypes, resembling different species and therefore leading to the conclusion that there was only one valid species: Ammonia beccarii (Linné, 1758). Consequently, Ammonia from the European marginal seas were commonly determined as A. beccarii, even though they showed morphological variability (Haake 1962; Lutze 1965; Murray 1991). Morphometric analyses of Ammonia populations globally inferred two discernable 'morphostocks' of large, ornamented A. beccarii and less ornamented Ammonia parkinsoniana (d'Orbigny, 1839) (Poag 1978; Jorissen 1988). Other varieties were assigned as form names to these two morphospecies (Jorissen 1988; Hayward et al. 1999). This concept was corroborated by the observation that the 'morphostocks' showed consistent differences in their ecological preferences (Debenay et al. 1998). In the North Sea and western Baltic Sea, the species names Ammonia batava (Hofker, 1951), A. beccarii, A. catesbyana (d'Orbigny 1839), A. flevensis (Hofker 1930) and A. tepida Cushman 1926 were used (Haake 1962; Lutze 1965; Brodniewicz 1965; Hofker 1977; Langer et al. 1989; Langer and Leppig 2000; de Nooijer 2007). The name A. tepida has also been used for populations from other European marginal seas (e.g. Bouchet et al. 2007; Pascal et al. 2008). However, the lectotypes of A. tepida from the West Indies show a different morphology, and this name should be avoided for populations from temperate regions (Hayward et al. 2003). A re-assessment of the taxonomic status of Ammonia populations based on phylogenetic analysis of variable regions D1 and D2 of the Large Subunit of ribosomal DNA (LSU rDNA) revealed thirteen different molecular types of Ammonia worldwide (Pawlowski et al. 1995; Holzmann 2000; Holzmann and Pawlowski 1997, 2000; Hayward et al. 2004; Pawlowski and Holzmann 2008). Eight of these phylotypes can be assigned to described species on the basis of morphological features, whereas the extensive use of the name A. beccarii should be abandoned (Hayward et al. 2004). Furthermore, the phylotype T6 has a disjunct distribution, in the Wadden Sea and marginal seas off Japan and northern China, where the names Ammonia aomoriensis (Asano 1951) and Ammonia "beccarii" forma 1 have been used (Nomura and Seto 1992; Xiang et al. 2008; Takata et al. 2006) The name A. aomoriensis was therefore proposed for the phylotype T6 (Hayward et al. 2004).

More than 60 morphospecies of Elphidium were reported in studies of recent foraminifers worldwide (Murray 1991). Several of them were identified in the North Sea and western Baltic Sea: Elphidium albiumbilicatum (Weiss, 1954), E. excavatum clavatum Cushman 1930, E. excavatum excavatum (Terquem 1876), E. gerthi van Voorthuysen, 1957, E. guntheri Cole, 1931, E. incertum (Williamson, 1858) and E. williamsoni Haynes, 1973 (Lutze 1965; Frenzel et al. 2005; Schönfeld and Numberger 2007a;
Nikulina et al. 2008; Polovodova and Schönfeld 2008). These species are easily distinguishable by their morphology (Lutze 1965). Nevertheless, the most confused taxonomic situation has always been associated with E. excavatum because of its high intraspecific variability (Feyling-Hanssen 1972; Miller et al. 1982). A total of eleven morphotypes, considered as either species, subspecies or ecophenotypes, have been described for E. excavatum (Goubert 1997). In the western Baltic Sea, the two subspecies E. e. excavatum and E. e. clavatum seem to co-occur, even though they show different depth preferences (Lutze 1965). For the time being, Elphidium has been studied much less than Ammonia with molecular phylogeny, and only a few sequences are deposited in the EMBL/ GenBank database.

\section{Ecology of Ammonia and Elphidium from the Kiel} Fjord

The Kiel Fjord is a narrow, N-S extending, 10-20 m deep inlet of the Kiel Bight in the western Baltic Sea. Its hydrography is characterised by a low-salinity surface water (10-19 psu), which is separated by a halocline at 16$18 \mathrm{~m}$ depth from the more saline Kattegat Water (17-21 psu). The prevailing Ammonia species, first identified as $A$. beccarii, is a shallow-water species living in muddy sands at a water depth of 4-14 m with brackish conditions of 1523 psu (Rottgardt 1952; Lutze 1965; Nikulina et al. 2008). The sediments in the Kiel Fjord are enriched in organic matter $\left(\mathrm{C}_{\text {org }}\right.$ : $3-5 \%$ and biogenic silica: $\left.3-7 \%\right)$ when compared to the Baltic Sea (Balzer 1984; Emelyanov 1988). They mirror a high bioproductivity of more than $200 \mathrm{~g} \mathrm{C} \mathrm{m}^{-2}$ year $^{-1}$ providing a sufficient amount of food for benthic foraminifera (Schönfeld and Numberger 2007b). Similar nutritional conditions were described by Irion (1994) in the tidal flats from Wilhelmshaven (North Sea) where Ammonia is frequent as well. In other fjords of the Kiel Bight, A. beccarii was found above the picnocline in sandy sediments with the lowest food concentration (Exon 1972; Polovodova et al. 2009), which confirms its opportunistic behaviour when compared to other foraminiferal species (Nikulina et al. 2008).

Among the Elphidium taxa considered in this study, $E$. gerthi occupies muddy sediments of the near-shore zones, and $E$. excavatum inhabits sandy-muds enriched in organic matter $\left(\mathrm{C}_{\text {org }}: 2-5 \%\right.$ and biogenic silica $\left.1-6 \%\right)$ of the Kiel Bight (Polovodova et al. 2009). According to Lutze (1965), E. excavatum is a deep-infaunal species, which is found down to $6 \mathrm{~cm}$ depth and occurs therefore mainly in well-oxygenated sediments with active water exchange. Two subspecies of E. excavatum are distinguished: $E$. $e$. excavatum is limited to the shallow areas of the Kiel Bight, whereas the cold-water-adapted E. e. clavatum 
Fig. 1 SEM pictures of Ammonia (a) and Elphidium (b) specimens collected in the Kiel Fjord with their DNA identification numbers. Scale bar $=100 \mu \mathrm{m}$
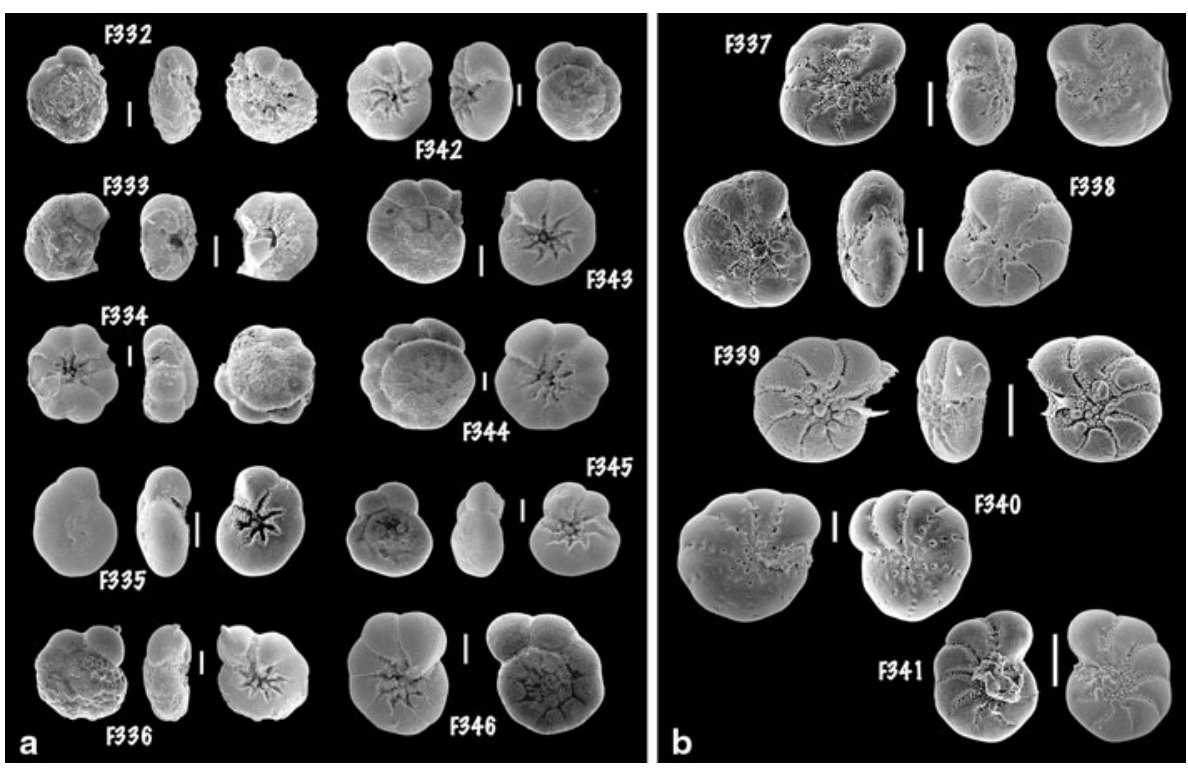

prefers the deeper areas in and below the halocline (Lutze 1965, 1974; Nikulina et al. 2008).

\section{Materials and methods}

\section{Sampling and SEM imaging}

Surface sediment samples were collected in the inner Kiel Fjord under the net cages of the "Kieler Lachsforelle" fish farm by SCUBA divers in September 2007. This site was chosen because the high food input and occurrence of different substrates promoted the co-occurrence of different species, which otherwise inhabited separated distribution areas in the fjord. Live foraminifers were distinguished from dead ones by natural colouration of the protoplasm and pseudopodial activity under a dissection microscope. Alive specimens were picked out, cleaned in filtered seawater with a paint brush, transferred to Eppendorf tubes and dried at room temperature. Ten Ammonia and five Elphidium (Fig. 1) specimens were imaged with a scanning electron microscope (SEM) at ETH Zurich for taxonomical documentation.

DNA extraction, amplification and sequencing

After SEM imaging, the 15 dried foraminiferal tests were crushed to extract DNA from each of them individually by the DOC method (Pawlowski 2000). The two regions of rDNA examined here correspond to 3' fragment of the SSU rRNA and 5' fragment of the LSU rRNA genes (Fig. 2). The SSU fragment (primers s14F3-sB for the amplification and $\mathrm{s} 14 \mathrm{~F} 1-\mathrm{sB}$ for the reamplification) is about 1,000 nucleotides (nt) and is widely used in foraminiferal studies. The LSU fragment (primers 2TA-L1F for the amplification and 2TA- L7 for the reamplification) was specifically used to recognise the different genotypes of Ammonia (e.g. Pawlowski et al. 1995) and represents a more variable and shorter fragment (about $400 \mathrm{nt}$ ). All positive amplifications were purified with the High Pure PCR Purification Kit (Roche Diagnostics) and sequenced directly using a BigDye Terminator v3.1 Cycle Sequencing Kit and an ABIPrism 3100 DNA sequencer (both Applied Biosystems), all according to the manufacturer's instructions.

Phylogenetic analysis

The new sequences (19 partial SSU and 11 partial LSU ones) have been deposited in the EMBL/GenBank database (accession numbers given in Tables 1, 2). The new sequences were aligned manually with related sequences available from GenBank in two separate datasets (SSU and LSU) using Seaview (Galtier et al. 1996). The sequences of Ammonia available from the EMBL/GenBank database are mainly LSU sequences (Pawlowski et al. 1994, 1995;

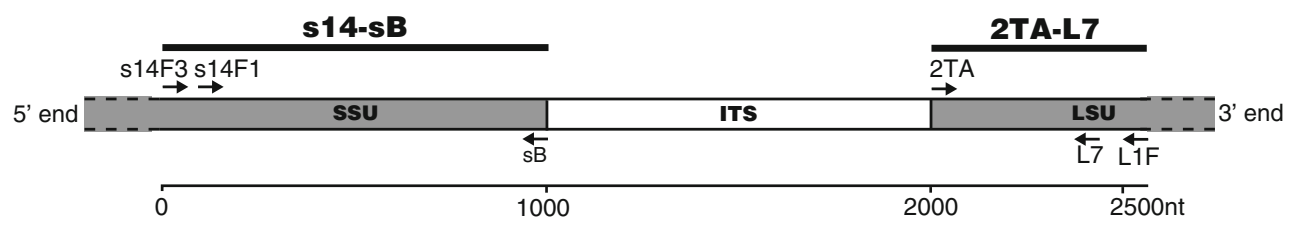

Fig. 2 Location of the primers used to amplify the SSU and LSU rDNA fragments 
Table 1 List of specimens from the Kiel Fjord with their DNA numbers and the EMBL/GenBank accession numbers

\begin{tabular}{llll}
\hline Species & DNA number & SSU sequence & LSU sequence \\
\hline Ammonia aomoriensis & F332 & GQ853570 & GQ853578 \\
Ammonia aomoriensis & F333 & GQ853571 & GQ853579 \\
Ammonia aomoriensis & F334 & GQ853572 & GQ853580 \\
Ammonia aomoriensis & F335 & GQ853573 & GQ853581 \\
Ammonia aomoriensis & F336 & Negative & Negative \\
Elphidium excavatum & F337 & GQ853563 & Negative \\
Elphidium excavatum & F338 & GQ853564 & Negative \\
Elphidium excavatum & F339 & GQ853565 & Negative \\
Elphidium excavatum & F340 & GQ853566 & Negative \\
Elphidium gerthi & F341 & Negative & Negative \\
Ammonia aomoriensis & F342 & Not done & GQ853582 \\
Ammonia aomoriensis & F343 & GQ853574 & GQ853583 \\
Ammonia aomoriensis & F344 & Not done & GQ853584 \\
Ammonia aomoriensis & F345 & GQ853575 & GQ853585 \\
Ammonia aomoriensis & F346 & Not done & GQ853586 \\
\hline
\end{tabular}

Holzmann et al. 1996; Holzmann and Pawlowski 2000; Hayward et al. 2004), but there are also some SSU sequences attributed to Ammonia sp., A. beccarii, A. catesbyana and A. tepida (Pawlowski et al. 1996, 1997; Langer and Leppig 2000; Ertan et al. 2004; Schweizer et al. 2008). Two environmental sequences (Habura et al. 2008) branching inside the Ammonia clade were also added. SSU sequences belonging to three species of Elphidium ( $E$. aculeatum (d'Orbigny, 1846), E. excavatum and E. williamsoni) are available from the EMBL/GenBank database (Pawlowski et al. 1997; Langer 2000; Ertan et al. 2004; Schweizer et al. 2008). One environmental sequence (Habura et al. 2008) branching in the clade of E. williamsoni was also added. The genus Haynesina was chosen as the out-group taxon, because it is the closest known relative of Ammonia and Elphidium (Schweizer et al. 2008).

The regions that were impossible to align properly were removed to obtain two final alignments of 820 sites for the
SSU and 286 sites for the LSU, from which 750 and 270 sites were, respectively, used for analyses (numbers of sites calculated with Phylo_Win, Galtier and others 1996).

Maximum likelihood (ML) analyses were performed with 100 bootstrap (BS) replicates by PhyML 2.4.4 (Guindon and Gascuel 2003) under the HKY (Hasegawa, Kishino, Yano) model (Hasegawa et al. 1985) for the SSU (Fig. 3) and the LSU (Fig. 4) alignments. In order to correct for among-site rate variations, the proportion of invariable sites (I) and the alpha parameter of gamma distribution $(\Gamma)$, with six rate categories, were estimated by PhyML (HKY $+\mathrm{I}+\Gamma)$. In addition, BIONJ phylogenetic trees (Gascuel 1997) were inferred with Phylo_Win under the K2P (Kimura's two parameter) evolution model (Kimura 1980) with non-parametric bootstrapping $(1,000$ replicates).

\section{Results}

Out of ten Kiel Fjord Ammonia extracted for DNA, all but one (F336) gave positive results for PCR. SSU sequences were obtained from six Ammonia specimens and LSU sequences from nine specimens (Table 1). Among the five specimens of Elphidium from the Kiel Fjord, which were extracted for DNA, all but F341 (E. gerthi) gave SSU sequences (Table 1). However, the results were negative for the LSU fragment. Because Elphidium has one of the fastest evolutionary rates among benthic foraminifers (Schweizer et al. 2008), these negative results could be due to the fact that the $5^{\prime}$ end of the LSU gene had slightly diverged in this genus, causing a mismatch error with LSU primers and preventing the DNA amplification.

\section{SSU rDNA analysis}

The topologies of ML (Fig. 3) and BIONJ (data not shown) trees were rather similar. Only the position of the Australian
Table 2 List of other new rDNA sequences with their DNA numbers, locality of sampling and EMBL/GenBank accession numbers. Samples 475, 476, 1244 and 3978 belong to the Forams DNA Collection in Geneva

\begin{tabular}{llll}
\hline Species & DNA number & Locality & Sequence name \\
\hline Haynesina germanica & F323 & Den Oever (NL) & GQ853557 (SSU) \\
Elphidium sp. & 1244 & GQ853576 (LSU) \\
Elphidium sp. & 3978 & Mok Baai (NL) & GQ853558 (SSU) \\
& & & GQ853559 (SSU) \\
& & Dunstaffnage (UK) & GQ853560 (SSU) \\
Ammonia sp. & 475 & & GQ853561 (SSU) \\
Ammonia sp. & 476 & Lizard Island (AUS) & GQ853562 (SSU) \\
Ammonia aomoriensis & F583 & Lizard Island (AUS) & GQ853567 (SSU) \\
Ammonia aomoriensis & A23 & Den Oever (NL) & GQ853569 (SSU) \\
\hline
\end{tabular}


Fig. 3 Molecular phylogeny of Ammonia and Elphidium based on partial SSU rDNA sequences inferred using the ML method $(\mathrm{HKY}+\mathrm{I}+\Gamma)$. Tree is rooted on $H$. germanica, and bootstrap values for ML and BIONJ analyses are indicated at the nodes

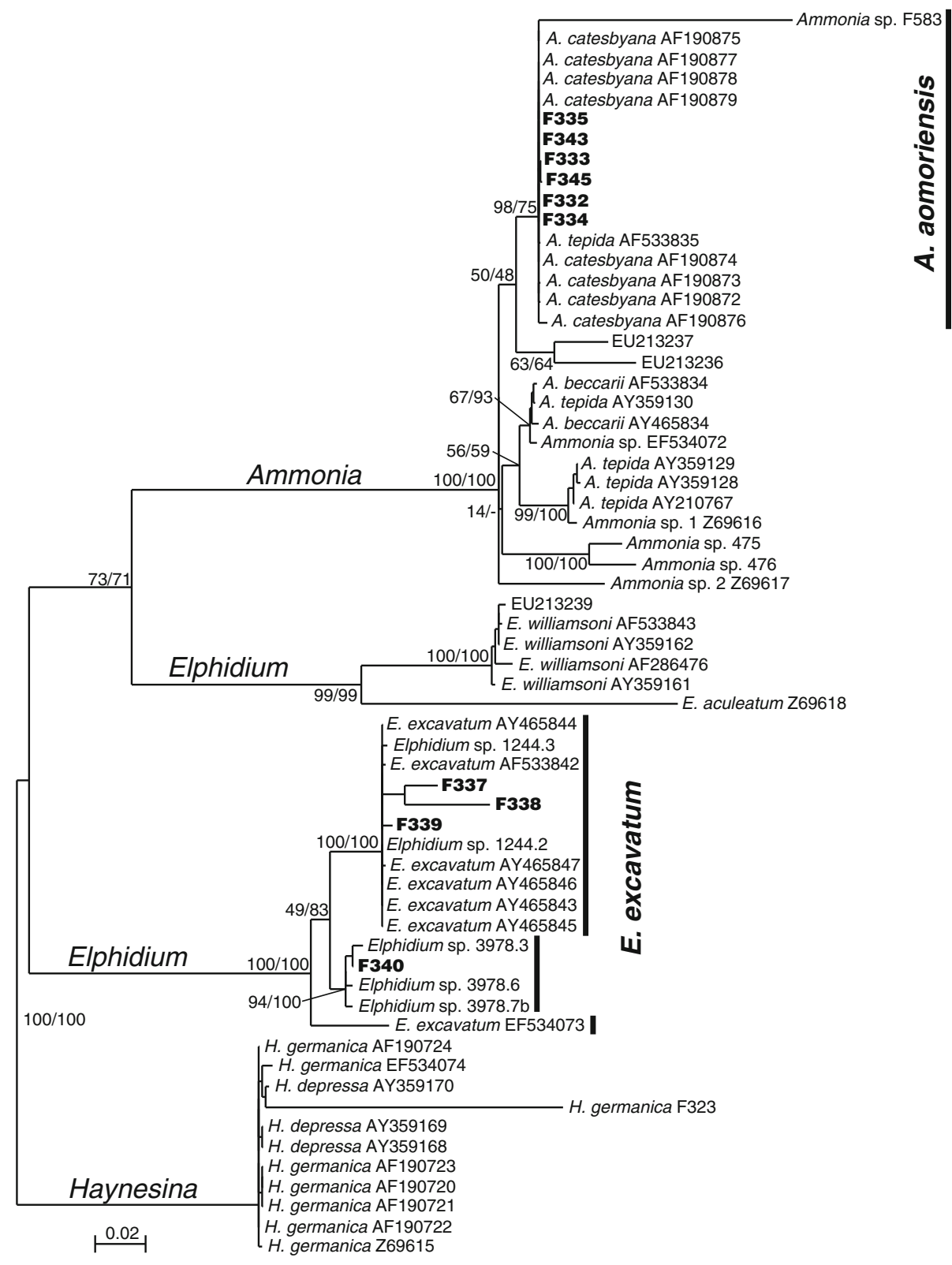

clade (475 and 476) inside the Ammonia clade moved slightly between both analyses. This difference in topology and the low statistical supports of the intermediate nodes were signs that the phylogenetic signal was too weak to infer robust relationships between clades due to the shortness of the studied region. However, the terminal clades were stable, with rather high BS (usually above 60\%).

The Ammonia sequences formed a monophyletic group (100\% BS), which was composed of six clades (Fig. 3). One of these clades included the six Ammonia sequences from the Kiel Fjord, the sequences of specimens named $A$. catesbyana from Crildumersiel in the Wadden Sea (Langer and Leppig 2000) and another sequence attributed to $A$. tepida from the North Frisian Islands (Ertan et al. 2004).
This clade had a high statistical support (98/75\% BS), and it was sister group to the two environmental sequences from USA.

The Elphidium sequences formed a paraphyletic group composed of two clades at the basis of the Ammonia clade (Fig. 3). The sister clade of Ammonia was composed of the sequences of E. williamsoni and E. aculeatum, and the most basal clade included the $E$. excavatum sequences. The E. excavatum clade subsumed three subclades: one with a sequence from Den Oever (EF534073, Schweizer et al. 2008), one with F340 and clones of a Scottish Elphidium (3978) and one with F337, F338, F339, six sequences from the Bay of Biscay (Ertan et al. 2004) and two from the Wadden Sea (1244). 


\section{LSU rDNA analysis}

The 13 phylotypes of Ammonia, which had been previously defined by Hayward et al. (2004), were also retrieved in this analysis (Fig. 4). The general topology of the tree was similar to the one published by Pawlowski and Holzmann (2008). The statistical supports of the 13 phylotypes were high; above $70 \%$ BS for most of them, but the other nodes had variable supports. This can be explained by the shortness of the fragment giving a weak phylogenetic signal of the deeper nodes. The nine LSU sequences of Ammonia from the Kiel Fjord branched in the phylotype T6 with a support of $72 / 97 \%$ BS, together with other European sequences from the Wadden Sea and Asian sequences from
China and Japan. All the sequences were very homogeneous with less than $1.5 \%$ divergence.

\section{Discussion}

Molecular identification of Ammonia specimens

Comparisons between SSU (Fig. 3) and LSU (Fig. 4) rDNA analyses are difficult because, except for the Kiel Fjord samples, different specimens were sequenced for both genes. Moreover, species names were attributed to SSU-analysed specimens (except Ammonia sp. 1 and 2 corresponding to $\mathrm{T} 1$ and $\mathrm{T} 2$, respectively) based on their
Fig. 4 Molecular phylogeny of Ammonia based on partial LSU rDNA sequences inferred using the ML method (HKY $+\mathrm{I}+\Gamma$ ). Tree is rooted on N. calcar, $P$. nipponica and $H$. germanica, and bootstrap values for ML and BIONJ analyses are indicated at the nodes

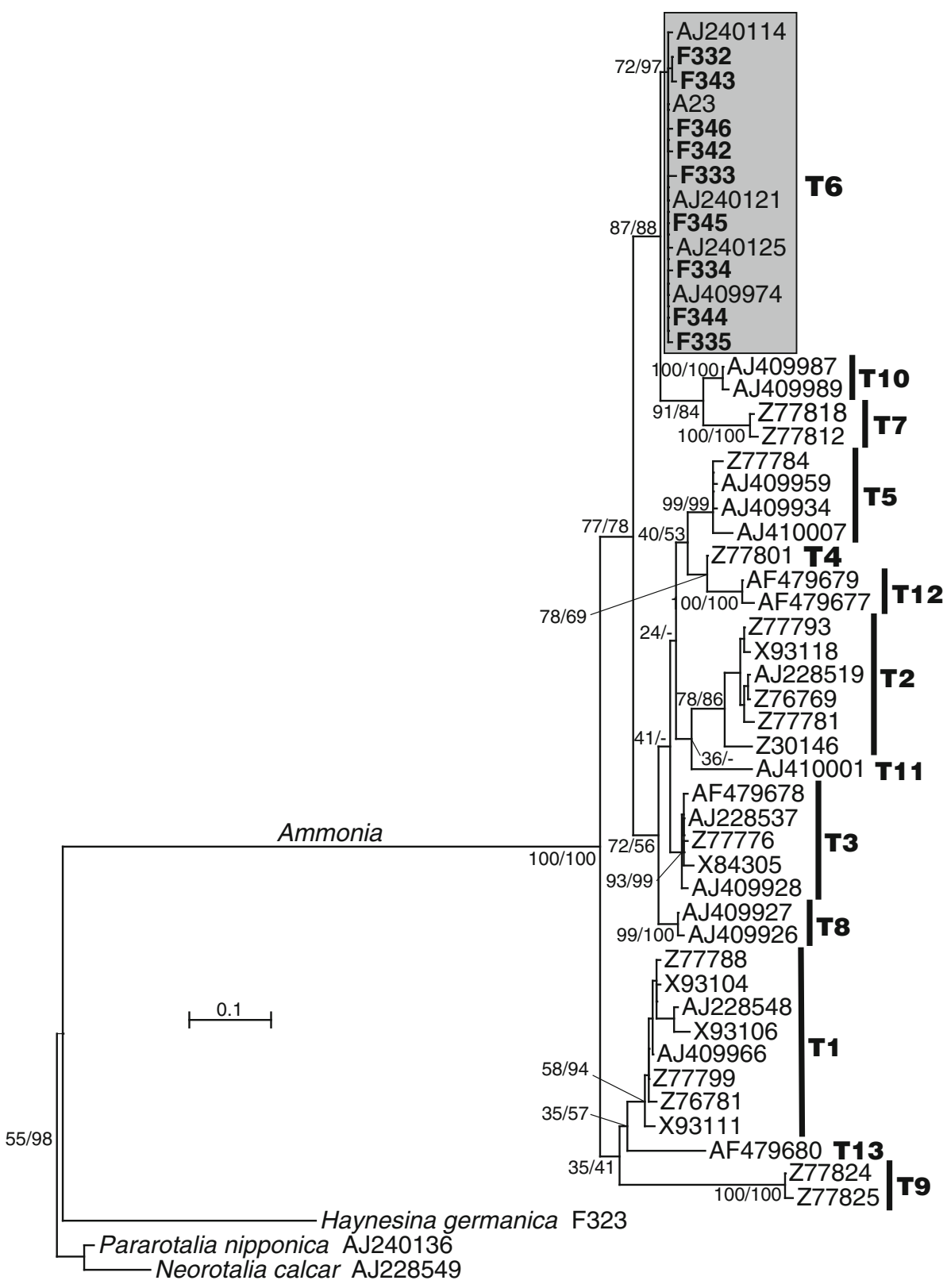


Fig. 5 Distribution of the phylotype T6 worldwide (a) and in the region of Wadden and West Baltic Seas (b). Sampled sites are indicated by circles for Asia and stars for Europe. Data from Hayward et al. (2004), Langer and Leppig (2000), Ertan et al. (2004) and the present study

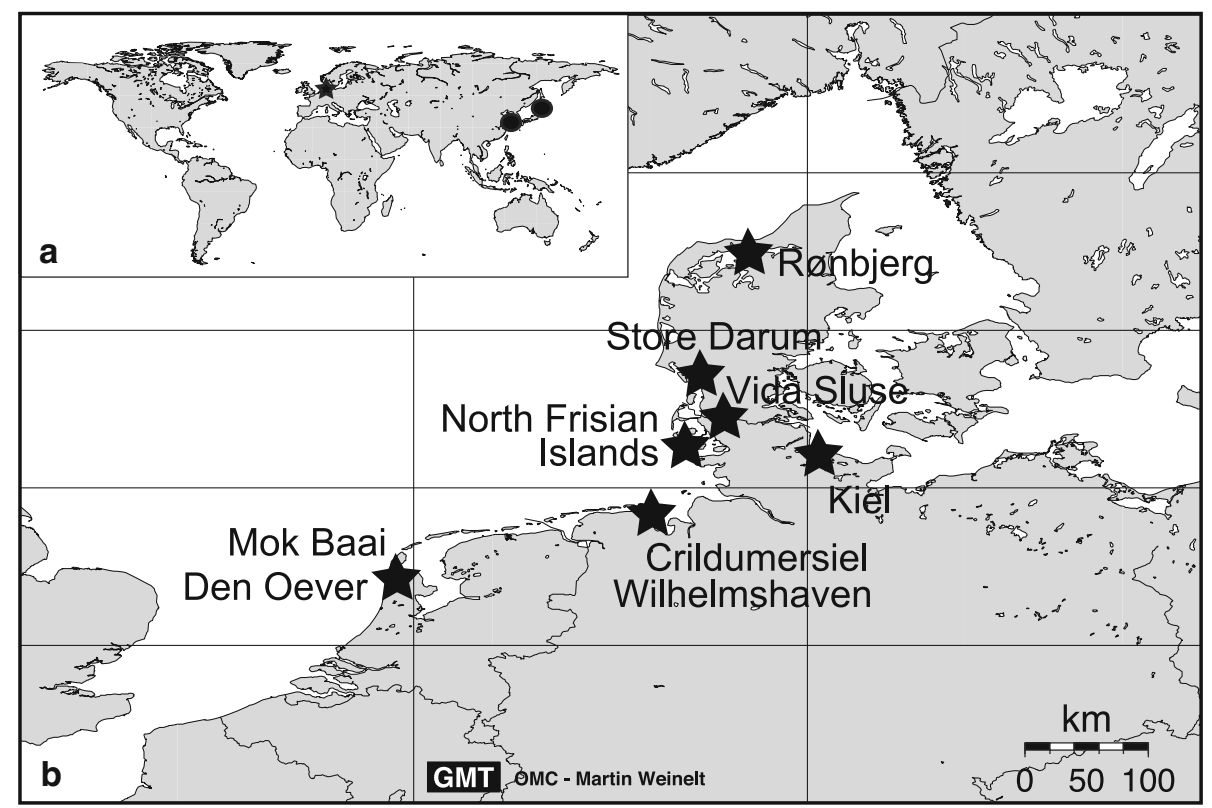

morphology, whereas LSU-analysed specimens were first defined as phylotypes and subsequently attributed to morphospecies (Hayward et al. 2004).

In the LSU analysis, the Kiel Fjord Ammonia branch within the phylotype T6. Other members of T6 have been collected in Japan (lakes in Hokkaido and Honshu) and China (Yalu Jiang), as well as in the Dutch (Mok Baai, Den Oever) and German (Wilhelmshaven) Wadden Sea and in Denmark (Fig. 5). In the SSU analysis, Kiel Fjord Ammonia group with specimens collected in Crildumersiel (near Wilhelmshaven) and identified as A. catesbyana (Langer and Leppig 2000) and with one sequence attributed to A. tepida and collected in the North Frisian Islands (Ertan et al. 2004). In view of the LSU results, these specimens can also be attributed to T6.

In Mok Baai, the phylotype T6 co-occurs with T1, the only phylotype with a cosmopolitan distribution (Pawlowski and Holzmann 2008). Moreover, it is difficult to discriminate morphologically T6 from T1, T2 and T10 because of the lack of salient characteristics (Hayward et al. 2004). Therefore, further studies with a wider sampling are needed to check whether T6 is the only phylotype present in the Kiel Fjord.

If we assume that the Ammonia populations from the Wadden and Baltic Seas represent mainly one genotype, which also occurs in eastern Asia, a consistent species name is required. The morphospecies $A$. beccarii, $A$. tepida and $A$. catesbyana have been described from very distant localities: Cuba and Martinique for A. catesbyana (d'Orbigny 1839), Rimini, Italy, for topotypic specimens of A. beccarii (Cushman 1928) and Puerto Rico for A. tepida (Cushman 1926). Moreover, there is currently no recognised phylotype corresponding to the morphology of these species (Hayward et al. 2004). Phylotype T6 specimens resemble morphologically the holotype of A. aomoriensis from the Pliocene Hamada Formation from Honshu (Hayward et al. 2004), a species also reported from unspecified recent deposits of northern Japan (Asano 1951). This phylotype was also related to A. beccarii forma 1 (Toyofuku et al. 2005), a morphotype often identified in Japanese studies (Nomura and Seto 1992; Takata et al. 2006). However, for the time being and on the basis of the molecular analyses, we propose to follow Hayward et al. (2004) by using the denomination of A. aomoriensis for the phylotype T6, including the populations from the European Wadden and Baltic Seas.

The most likely explanation for this disjunct distribution is the transport of Asian individuals through water used for ships' ballast (Pawlowski and Holzmann 2008). This hypothesis is strengthened by the fact that most of the sampled localities in Europe are close to harbours and that Ammonia is apparently a newcomer in the Kiel Fjord. A core taken from the outer Kiel Fjord, with a record approximately going back to 1950, showed that Ammonia was always absent or rare until 2000 when it became abundant (Polovodova and Nikulina, unpublished data). So, we could speculate that local Ammonia species were transported regularly with bottom water inflows from the North Sea to the western Baltic Sea but perished due to inadequate salinity conditions as suggested for species that occur sporadically or as single specimens (Brodniewicz 1965). The abundance of Ammonia observed since the year 2000 could therefore be explained by the arrival of the newcomer A. aomoriensis, brought to the North Sea with ships' ballast and then following the same way than former indigenous Ammonia species, but settling successfully in 
the western Baltic Sea because it was better adapted to this brackish environment.

\section{Molecular identification of Elphidium specimens}

Seven different Elphidium taxa were reported from the Kiel Bight, and they were attributed to the genera Elphidium, Cribrononion or Cribroelphidium (Lutze 1965, 1974; Frenzel et al. 2005; Nikulina et al. 2008). Two taxa were considered as subspecies of Elphidium excavatum, namely E. e. excavatum (forma selseyensis of Frenzel et al. 2005) and E. e. clavatum. The distinction between both taxa was initiated by Lutze (1965), who had topotypic specimens of Elphidium excavatum from Dunkerque, France and samples from the Arctic with Elphidium clavatum available, and he compared them with his specimens from the Baltic Sea for species determination. The discernation concept was later corroborated by morphological, biogeographical and evolutionary studies (Feyling-Hanssen 1972; Miller et al. 1982; Goubert 1997; Poignant et al. 2000). Elphidium e. excavatum was originally described from beach sands off Dunkerque, France (Terquem 1876). Tests of E. e. excavatum exhibit numerous papillae of different sizes in the umbilical area. They are surrounded by thickened extensions of the chamber walls pointing into the umbilicus. The sutural bridges are generally indistinct. The test of Elphidium e. excavatum is slightly compressed with a width *10/diameter ratio of 4-5 (Lutze 1965). The other subspecies, Elphidium e. clavatum, was described from Frenchmans Bay, Maine, USA (Cushman 1930). Tests of E. e. clavatum show a central knob in the umbilical area. The sutural bridges are broad and distinct, and the sutures close before reaching the umbilicus. Elphidium e. clavatum is with a width * 10/diameter ratio of 5-6 markedly thicker than E. e. excavatum. Our specimens F337-F339 were morphologically attributed to E. e. excavatum, because their tests have wide sutural and umbilical areas, which harbour pustules. The test of F340 is stouter (higher width/ diameter ratio of the profile) and shows clear sutural bridges crossing simple sutures that radiate from a closed umbilicum; therefore, it was identified as E. e. clavatum (Fig. 1). The DNA results have confirmed the attribution to E. excavatum as well as the distinction in two subgroups (Fig. 3). The three subclades subsumed in E. excavatum (Fig. 3) may correspond to some of the different morphotypes previously described (e.g. Goubert 1997). These subclades cannot be considered as ecophenotypes (e.g. Miller et al. 1982) because of their genetic differentiation, but they represent different subspecies or species.

Elphidium excavatum excavatum and E. e. clavatum usually inhabit different depth intervals in the western Baltic Sea with different hydrographic and sedimentary environments (Lutze 1965, 1974). To consider them as different subspecies or species implies spatially or temporally isolated populations with rather limited gene exchanges. In the western Baltic Sea, both taxa were occasionally found co-occurring in the living assemblage or exchanging each other in shallow-water areas over the year (Lutze 1965; Haake 1967). The present study brings supplementary genetic evidence of the co-occurrence of these taxa.

\section{Conclusion}

Molecular identification with rDNA sequences gives clear answers, which can help untangling a complex taxonomy when coupled with a morphological study. The present results are particularly good for a genus already well studied phylogenetically such as Ammonia, but answers are also obtained for a genus with fewer sequences published such as Elphidium.

The Ammonia specimens collected in the Kiel Fjord belong to clade T6 (Figs. 3, 4), a phylotype reported from China and Japan, which has been also found in the Wadden and Baltic Seas and the Danish Skagerrak (Fig. 5). According to Hayward et al. (2004), the Ammonia belonging to the phylotype T6 are referable on morphological characters to the Japanese species A. aomoriensis. However, this species has been described from the Pliocene, and whether it is extant or not has to be investigated. Likewise, further sampling is needed in the western Baltic Sea to verify whether T6 is the only Ammonia phylotype present in this area.

The Elphidium specimens from the Kiel Fjord belong to the species E. excavatum. Moreover, the phyloclade $E$. excavatum is composed of at least three subclades (Fig. 3), which mirrors the high morphological diversity translated in the description of different ecophenotypes, subspecies or species (Feyling-Hanssen 1972). The large genetic differences between specimens determined as E. e. excavatum and E. e. clavatum corroborate the evidence for their discrimination as subspecies rather than ecophenotypes. Further investigations are needed to understand the relationships between these different types of E. excavatum, their taxonomic status, the connection between genetic and morphological variability and their ecology.

Acknowledgments We would like to thank Volker Liebetrau, Michael Albrecht and the International Diving Association (Kiel, Germany) who collected the sediment samples in the Kiel Fjord, Tassilo Jäger-Kleinicke for permission to dive under his net cages, Jan Pawlowski who gave us access to the Forams DNA Collection in Geneva and Bruce Hayward and an anonymous reviewer for their useful comments that improved the manuscript. This study was supported by the Swiss National Science Foundation (grant 200020109639/1 to M. S.) and the Leibniz Award DFG DU 129-33 (to I. P. and A. N.). 


\section{References}

Asano K (1951) Part 14: Rotaliidae. In: Stach LW (ed) Illustrated catalogue of Japanese Tertiary smaller foraminifera. Hosokawa Printing, Tokyo, pp 1-21

Balzer W (1984) Organic matter degradation and biogenic element cycling in a nearshore sediment (Kiel Bight). Limnol Oceanogr 29:1231-1236

Bouchet VMP, Debenay JP, Sauriau PG, Radford-Knoery J, Soletchnik P (2007) Effects on short term environmental disturbances on living benthic foraminifera during the Pacific oyster summer mortality in the Marennes-Oléron Bay (France). Mar Environ Res 64:358-383

Brodniewicz I (1965) Recent and some Holocene Foraminifera of the southern Baltic Sea. Acta Palaeontol Pol 10(2):131-259

Cushman JA (1926) Recent foraminifera from Porto Rico. Publ. Carnegie Institution Washington 342:73-84

Cushman JA (1928) On Rotalia beccarii (Linné). Contrib. Cushman Found. Foram Res 4:103-107

Cushman JA (1930) The foraminifera of the Atlantic Ocean, pt. 7: Nonionidae, Camerinidae, Peneroplidae, and Alveolinellidae. US National Museum Bull 104(7):1-79

d'Orbigny A (1839) Foraminifères. In: de la Sagra R (ed) Histoire physique et naturelle de l'île de Cuba. Bertrand, Paris

de Nooijer LJ (2007) Shallow-water benthic foraminifera as proxy for natural versus human induced environmental change. Geologica Ultraiectina 272:1-152

Debenay JP, Beneteau E, Zhang J, Stouff V, Geslin E, Redois F, Fernandez-Gonzalez M (1998) Ammonia beccarii and Ammonia tepida (Foraminifera): morphofunctional arguments for their distinction. Mar Micropaleontol 34:235-244

Ellis BFS, Messina AR (1940) Catalogue of foraminifera. Special Publication, American National Museum, New York

Emelyanov EM (1988) Biogenic sedimentation in the Baltic Sea and its consequences. In: Winterhalter B (ed) The Baltic Sea Geological Survey of Finland, vol 6, Special Paper, pp 127-135

Ertan KT, Hemleben V, Hemleben C (2004) Molecular evolution of some selected benthic foraminifera as inferred from sequences of the small subunit ribosomal DNA. Mar Micropaleontol 53:367-388

Exon N (1972) Sedimentation in the outer Flensburg Fjord area (Baltic Sea) since the last Glaciation. Meyniana 22:5-6

Feyling-Hanssen RW (1972) The foraminifera Elphidium excavatum (Terquem) and its variant forms. Micropaleontology 18(3):337354

Frenzel P, Tech T, Bartholdy J (2005) Checklist and annotated bibliography of recent Foraminiferida from the German Baltic Sea coast. Stud Geol Pol 124:67-86

Galtier N, Gouy M, Gautier C (1996) SEAVIEW and PHYLO_WIN: two graphic tools for sequence alignment and molecular phylogeny. Comput Appl Biosci 12:543-548

Gascuel O (1997) BIONJ: an improved version of the NJ algorithm based on a simple model of sequence data. Mol Biol Evol 14(7):685-695

Goubert E (1997) Le groupe Elphidium excavatum (Terquem): stratégie adaptive des formes lidoensis Cushman et selseyensis (Heron-Allen and Earland) en Baie de Vilaine (Bretagne, France) et lignée évolutive. Geobios 21:303-310

Guindon S, Gascuel O (2003) A simple fast and accurate algorithm to estimate large phylogenies by maximum likelihood. Syst Biol 52(5):696-704

Haake FW (1962) Untersuchungen an der Foraminiferen-Fauna im Wattgebiet zwischen Langeoog und dem Festland. Meyniana 12:25-64

Haake FW (1967) Zum Jahresgang von Populationen einer Foraminiferen-Art in der westlichen Ostsee. Meyniana 17:13-27
Habura A, Goldstein ST, Broderick S, Bowser SS (2008) A bush not a tree: the extraordinary diversity of cold-water basal foraminiferans extends to warm-water environments. Limnol Oceanogr 53(4):1339-1351

Hasegawa M, Kishino H, Yano TA (1985) Dating of the human-ape splitting by a molecular clock of mitochondrial DNA. J Mol Evol 22:160-174

Hayward BW, Grenfell HR, Reid CM, Hayward KA (1999) Recent New Zealand shallow-water benthic foraminifera: taxonomy, ecologic distribution, biogeography and use in paleoenvironmental assessment. Institute of Geological and Nuclear Sciences Monograph 20:258

Hayward BW, Buzas MA, Buzas-Stephens P, Holzmann M (2003) The lost types of Rotalia beccarii var. tepida Cushman 1926. J Foramin Res 33:352-354

Hayward BW, Holzmann M, Grenfell HR, Pawlowski J (2004) Morphological distinction of molecular types in Ammoniatowards a taxonomic revision of the world's most common and misidentified foraminiferal genus. Mar Micropaleontol 50:237-271

Hofker J (1977) The foraminifera of Dutch tidal flats and salt marshes. Neth J Sea Res 11:223-296

Holzmann M (2000) Species concept in foraminifera: Ammonia as a case study. Micropaleontology 46(suppl. 1):21-37

Holzmann M, Pawlowski J (1997) Molecular morphological and ecological evidence for species recognition in Ammonia (Foraminifera). J Foramin Res 27(4):311-318

Holzmann M, Pawlowski J (2000) Taxonomic relationships in the genus Ammonia (Foraminifera) based on ribosomal DNA sequences. J Micropalaeontol 19:85-95

Holzmann M, Piller W, Pawlowski J (1996) Sequence variations in the large-subunit ribosomal RNA gene of Ammonia (Foraminifera Protozoa) and their evolutionary implications. J Mol Evol 43:145-151

Irion G (1994) Schwermetalle in Nordseesedimenten. Natur und Museum 124:146-159

Jorissen FJ (1988) Benthic foraminifera from the Adriatic Sea: principles of phenotypic variation. Utrecht Micropaleontol Bull 37:66-83

Kimura M (1980) A simple method for estimating evolutionary rates of base substitutions through comparative studies of nucleotide sequences. J Mol Evol 16:111-120

Kubisch M, Schönfeld J (1985) Eine neue “Cyprinen-Ton”-Scholle bei Stohl (Schleswig-Holstein): Mikrofauna und Grobfraktionsanalyse von Sedimenten der Eem-zeitlichen Ostsee. Meyniana 37:89-95

Langer MR (2000) Comparative molecular analysis of small-subunit ribosomal 18S DNA sequences from Haynesina germanica (Ehrenberg 1840), a common intertidal foraminifer from the North Sea. Neues Jahrb. Geol. P.-M. 2000(11):641-650

Langer MR, Leppig U (2000) Molecular phylogenetic status of Ammonia catesbyana (d'Orbigny, 1839), an intertidal foraminifer from the North Sea. Neues Jahrb Geol P-M 2000:545-556

Langer MR, Hottinger L, Huber B (1989) Functional morphology in low-diverse benthic foraminiferal assemblages from tidal flats of the North Sea. Senckenb Marit 20:81-99

Lutze GF (1965) Zur Foraminiferen: Fauna der Ostsee. Meyniana $15: 75-142$

Lutze GF (1974) Foraminiferen der Kieler Bucht (westliche Ostsee): 1 "Hausgartengebiet" des Sonderforschungsbereiches 95 der Universität Kiel. Meyniana 26:9-22

Miller AL, Scott DB, Medioli F (1982) Elphidium excavatum (Terquem): ecophenotypic versus subspecific variation. J Foramin Res 12:116-144

Murray JW (1991) Ecology and paleoecology of benthic foraminifera. Longman, Harlow 
Murray JW (2006) Ecology and applications of benthic foraminifera. Cambridge University Press, Cambridge

Nikulina A, Polovodova I, Schönfeld J (2008) Foraminiferal response to environmental changes in Kiel Fjord, SW Baltic Sea. Earth 3:37-49

Nomura R, Seto K (1992) Benthic foraminifera from brackish lake Nakanoumi San in district southwestern Honshu Japan. In: Ishizaki K, Saito T (eds) Centenary of Japanese micropaleontology. Terra Publishing, Tokyo, pp 237-240

Pascal PY, Dupuy C, Richard P, Niquil N (2008) Bacterivory in the common foraminifer Ammonia tepida: isotope tracer experiment and the controlling factors. J Exp Mar Biol Ecol 359:55-61

Pawlowski J (2000) Introduction to the molecular systematics of foraminifera. Micropaleontology 46(suppl 1):1-12

Pawlowski J, Holzmann M (2008) Diversity and geographic distribution of benthic foraminifera: a molecular perspective. Biodivers Conserv 17(2):317-328

Pawlowski J, Bolivar I, Guiard-Maffia J, Gouy M (1994) Phylogenetic position of Foraminifera inferred from LSUrRNA gene sequences. Mol Biol Evol 11:929-938

Pawlowski J, Bolivar I, Fahrni JF, Zaninetti L (1995) DNA analysis of "Ammonia beccarii" morphotypes: one or more species? Mar Micropaleontol 26:171-178

Pawlowski J, Bolivar I, Fahrni JF, Cavalier-Smith T, Gouy M (1996) Early origin of foraminifera suggested by SSU rRNA gene sequences. Mol Biol Evol 13(3):445-450

Pawlowski J, Bolivar I, Fahrni JF, de Vargas C, Gouy M, Zaninetti L (1997) Extreme differences in rates of molecular evolution of foraminifera revealed by comparison of ribosomal DNA sequences and the fossil record. Mol Biol Evol 14(5):498-505

Poag CW (1978) Paired foraminiferal ecophenotypes in Gulf Coast estuaries: ecological and paleoecological implications. T Gulf Coast Assoc Geol Soc 28:395-421

Poignant A, Mathieu R, Levy A, Cahuzac B (2000) Haynesina germanica (Ehrenberg), Elphidium excavatum (Terquem) L. S. and Porosononion granosum (d'Orbigny) marginal-littoral species of Foraminifera from the Central Aquitaine (SW France) in the Middle Miocene (Langhian): the problem of Elphidium lidoense Cushman. Rev Micropaleont 43:233-245
Polovodova I, Schönfeld J (2008) Foraminiferal test abnormalities in the Western Baltic Sea. J Foramin Res 38(4):318-336

Polovodova I, Nikulina A, Schönfeld J, Dullo WC (2009) Recent benthic foraminifera in the Flensburg Fjord (Western Baltic Sea). J Micropalaeontol 28:131-142

Rottgardt D (1952) Mikropaläontolgische wichtige Bestandteile rezenter brackischer Sedimente an den Küsten SchlewigHolsteins. Meyniana 1:169-228

Schnitker D (1974) Ecotypic variation in Ammonia beccarii (Linné). J Foramin Res 4:217-223

Schönfeld J, Numberger L (2007a) The benthic foraminiferal response to the 2004 spring bloom in the western Baltic Sea. Mar Micropaleontol 65:78-95

Schönfeld J, Numberger L (2007b) Seasonal dynamics and decadal changes of benthic foraminiferal assemblages in the western Baltic (NW Europe). J Micropalaeontol 26:47-60

Schweizer M, Pawlowski J, Kouwenhoven TJ, Guiard J, van der Zwaan GJ (2008) Molecular phylogeny of Rotaliida (Foraminifera) based on complete small subunit rDNA sequences. Mar Micropaleontol 66:233-246

Takata H, Takayasu K, Hasegawa S (2006) Foraminifera in an organic-rich brackish-water lagoon, Lake Saroma, Hokkaido, Japan. J Foramin Res 36:44-60

Terquem O (1876) Essai sur le classement des animaux qui vivent sur la plage et dans les environs de Dunkerque, pt. 1. Mémoires de la Société Dunkerquoise pour l'Encouragement des Sciences, des Lettres et des Arts (1874-1876) 19:405-457

Toyofuku MS, Kitazato H, Tsuchiya M (2005) Phylogenetic relationships among genus Ammonia (Foraminifera) based on ribosomal DNA sequences which are distributed in the vicinity of the Japanese Islands. Front Res Earth Evol 2(2):1-10

Walton WR, Sloan BJ (1990) The genus Ammonia Brünnich 1772: its geographic distribution and morphologic variability. J Foramin Res 20:128-156

Xiang R, Yang Z, Saito Y, Fan D, Chen M, Guo Z, Chen Z (2008) Paleoenvironmental changes during the last 8400 years in the southern Yellow Sea: benthic foraminiferal and stable isotopic evidence. Mar Micropaleontol 67:104-119 